Article - Food/Feed Science and Technology

\title{
Production of Hydrolysate of Okara Protein Concentrate with High Antioxidant Capacity and Aglycone Isoflavone Content
}

Vitória Ribeiro Garcia de Figueiredo ${ }^{1}$ https://orcid.org/0000-0003-3636-591X

Ariana Justus ${ }^{1}$

https://orcid.org/0000-0002-2539-0143

Dafne Garcia Pereira ${ }^{1}$

https://orcid.org/0000-0003-3021-7211

Sandra Regina Georgetti ${ }^{2}$

https://orcid.org/0000-0003-2580-8762

\section{Elza louko Ida ${ }^{1^{*}}$}

https://orcid.org/0000-0002-5128-6366

\section{Louise Emy Kurozawa ${ }^{1,3^{*}}$}

https://orcid.org/0000-0001-9023-4393

${ }^{1}$ State University of Londrina, Department of Food Science and Technology, Londrina, PR, Brazil; ${ }^{2}$ State University of Londrina, Department of Pharmaceutical Sciences, Londrina, PR, Brazil; 3University of Campinas, Department of Food Engineering, Campinas, SP, Brazil

Received: 2018.07.03; Accepted: 2019.06.22.

* Correspondence: louisek@unicamp.br; Tel.: +55-19-35214032

\section{HIGHLIGHTS}

- We optimized the enzymatic hydrolysis of protein concentrate from okara

- During hydrolysis, there was a conversion of $\beta$-glycosides to aglycones isoflavones

- Enzymatic hydrolysis favors the exposure of antioxidant amino acids in proteins

- Protein hydrolysate had higher antioxidant activity than protein concentrate

Abstract: This work aimed to evaluate the enzymatic hydrolysis of okara protein concentrate with respect to degree of hydrolysis (DH) in order to obtain a protein hydrolysate with high antioxidant capacity and aglycones isoflavone content. A central composite rotatable design was carried out to evaluate the influence of temperature (40 to 
$\left.70^{\circ} \mathrm{C}\right)$, enzyme:substrate ratio $(0.5$ to $5.0 \%, \mathrm{~g} / 100 \mathrm{~g}$ protein) and $\mathrm{pH}(7.0$ to 9.0$)$ on $\mathrm{DH}$. The optimal condition was $55^{\circ} \mathrm{C}, \mathrm{pH} 9$ and enzyme:substrate ratio of $5.0 \%$, resulting a $\mathrm{DH}$ value of $35.5 \%$. After protein hydrolysis at optimal condition, the antioxidant capacities of hydrolysate increased from 58.29 to $383.49 \mu \mathrm{M}$ Trolox equivalent/g solids (ABTS method) and 2.41 to $15.32 \mu \mathrm{M}$ Trolox equivalent/g solids (FRAP method) when compared with protein concentrate. The higher radical scavenging ability of hydrolysate was due to great amount of hydrophobic amino acids (34.92 $\mathrm{g} / 100 \mathrm{~g}$ protein). Moreover, the protein hydrolysate obtained under optimal condition had 3 times higher aglycone isoflavone content than non-hydrolyzed sample. These results showed that protein hydrolysis of okara could be an alternative approach to increase antioxidant activity and enrich aglycones isoflavone in this byproduct generated from soymilk industry.

Keywords: soy pulp; peptides; cleavage of protein; isoflavone profile; electrophoresis; experimental design.

\section{INTRODUCTION}

In the production of soymilk and tofu, about one kilogram of the byproduct okara is generated from every kilogram of soybeans [1]. Although okara has been usually used as animal feed due to its little market value, it has considerable protein content $(40 \mathrm{~g} / 100 \mathrm{~g}$ solids) with high nutritional value [2]. Protein hydrolysis of okara could be an alternative process to recover the nutrients normally discarded and to obtain value-added peptides.

Protein hydrolysates can be used as functional or nutritional ingredients for food of low protein quality. Since they are an excellent source of peptides of low molecular weight, hydrolysates have a high digestibility, which depends on length, structure of the polypeptide chains and amino acid composition [3]. Furthermore, when released by hydrolysis, these peptides, which are in an inactive state within the sequence of the intact protein, present biological properties. Bioactive peptides have higher ability in reducing the reactivity of free radicals due to the exposure of amino acids that react more effectively with these radicals activity [4].

In addition, okara presents $0.02-0.12 \%$ (dry basis) of isoflavones, which represents about $12-40 \%$ of total isoflavones initially in the soybeans [5]. Isoflavones have four different chemical forms: $\beta$-glycosides, acetyl-glucosides, malonyl-glucosides and aglycones. The soybean isoflavones have been recognized by their benefits to human health due to several biological activities, among them, antioxidant properties [6]. The antioxidant capacity of isoflavones is due to the number of hydroxyl groups present in their chemical structure, and this ability decreases with glycosylation or substitution of methoxyl group. Thus, the antioxidant activity of aglycones is higher than other chemical forms, in particular genistein isomer [6].

Enzyme concentration, $\mathrm{pH}$ and temperature are the most important variables in the enzymatic hydrolysis reaction. The control of them is necessary in order to obtain a product with desired characteristics [7]. In addition, it is essential to optimize the process parameters with respect to degree of hydrolysis (DH) to develop an economical process. Degree of hydrolysis measures the extent of cleavage of proteins and represents the ratio of the number of peptide bonds hydrolyzed and the total number of bonds available for proteolytic reaction [7].

Furthermore, in the results found by our research group (Sbroggio et al. [8]), it was verified that the ABTS and DPPH free radicals scavenging ability and ferric reduction antioxidant power (FRAP assay) of protein hydrolysates of okara obtained by Alcalase increased significantly when the $\mathrm{DH}$ varied from 0 to $33.6 \%$. Other authors also reported a positive effect of $\mathrm{DH}$ on antioxidant capacity $[9,10]$ by increasing exposition of bioactive peptides. In addition, Lu et al. [11] reported a gradual decrease in isoflavone glycosides, accompanied by an increase in aglycones, in the course of protein hydrolysis time. This result can be due to the fact that the cleavage of protein favors the release of isoflavones 
associated with the interior of globular soybean proteins [12,13]. Thus, it can be expected that the higher protein hydrolysis extension (or $\mathrm{DH}$ values), the more susceptible the malonyl- and acetylglycoside isoflavones are for conversion into $\beta$-glycosides after heating, which can be hydrolyzed to aglycones by endogenous $\beta$-glycosidase, heat or acid/alkaline treatment [14].

Therefore, since our previous work demonstrated that higher $\mathrm{DH}$ values resulted in protein hydrolysate with greater antioxidant capacity and the literature reported the positive effect of protein hydrolysis extension on aglycone isoflavone formation, the aim of this study was to optimize the enzymatic hydrolysis with respect to $\mathrm{DH}$ and evaluate the protein hydrolysate obtained under optimal condition.

\section{MATERIAL AND METHODS}

\section{Materials}

Moist okara was acquired from a local industry of processing of soymilk. During the processing, okara was collected and forwarded to the city of Londrina, PR, Brazil. As soon as the material arrived in the laboratory, it was dried in a forced-air oven at $40^{\circ} \mathrm{C}$ for $24 \mathrm{~h}$, milled in a knife mill, defatted with $n$-hexane $(1: 10, w / v)$ under orbital agitation (MA-140, Marconi, Piracicaba, Brazil) for $30 \mathrm{~min}$ at $300 \mathrm{rpm}$ and room temperature, vacuum filtered and stored in a domestic refrigerator until analysis. Chemical composition (dry weight basis) of the deffated flour okara (DFO) [15], was: moisture content of $18.3 \pm 0.1 \%$, protein content of $31.7 \pm 0.8 \%$, fat content of $3.0 \pm 0.2 \%$, ash content of $5.3 \pm 0.3 \%$ and total fiber content of $60.2 \pm 1.4 \%$, in which insoluble and soluble fiber content were $58.9 \pm 1.6 \%$ and $1.4 \pm 0.1 \%$, respectively.

A multi-enzymatic complex Viscozyme (Novozymes, Bagsvaerd, Denmark), which consists of cellulase, hemicellulase, xylanase and $\beta$-glucanase, was used to enhance protein extraction of defatted flour okara. This enzyme has activity declared of $100 \mathrm{FBG} / \mathrm{g}$, wherein each FBG is the amount of enzyme required in a standard condition $\left(30^{\circ} \mathrm{C}, \mathrm{pH} 5.0\right)$ to hydrolyze $\beta$-glucans. For protein enzymatic hydrolysis, the protease Alcalase $2.4 \mathrm{~L}$ (Novozymes, Bagsvaerd, Denmark) was used. This protease has declared activity of 2.4 $A U-A / g$. One Anson Unit $(A U)$ is one milliequivalent of tyrosine released from hemoglobin per minute of hydrolysis.

\section{Preparation of protein concentrate from okara}

Before protein extraction, DFO was pretreated with Viscozyme in order to enhance protein extraction. DFO was added to phosphate citrate buffer $\mathrm{pH}$ 6.2. The mixture was kept under orbital agitation in a controlled temperature water bath (T-53, Tecnal, Piracicaba, Brazil). When the temperature of $53^{\circ} \mathrm{C}$ was reached, Viscozyme was added to a concentration of $4.0 \%$ and the sample was kept for $2 \mathrm{~h}$ in the bath. After sample pretreatment, protein extraction was performed $\left(\mathrm{pH} 9,60^{\circ} \mathrm{C}, 30 \mathrm{~min}\right)$, followed by isoelectric precipitation of proteins $(\mathrm{pH} 4.5)$. These conditions were established in a previous work. The protein concentrate presented $56.4 \%$ of protein content $(\mathrm{db})$.

\section{Enzymatic hydrolysis of okara protein concentrate}

A central composite rotatable design (CCRD) was carried out in order to evaluate the effect of temperature $\left(40\right.$ to $\left.70^{\circ} \mathrm{C}\right)$, enzyme:substrate ratio $(0.5$ to $5 \%$, g enzyme $/ 100 \mathrm{~g}$ protein) and $\mathrm{pH}$ (7.0 to 9.0) on degree of hydrolysis (DH) of okara protein concentrate (Table 1). Three central points (assays $15-17$ ) were carried out in order to verify the repeatability of hydrolysis process [16].

The hydrolysis experiments were performed according to $\mathrm{pH}$-stat method [7]. Two grams of lyophilized okara protein concentrate were homogenized with $100 \mathrm{~g}$ of distilled water in a jacketed $250 \mathrm{~mL}$ beaker. The solution was stirred constantly using a magnetic stirrer and heated using a thermostatically controlled water bath with external circulation 
(TE-2005, Tecnal, Piracicaba, Brazil). After reaching the desired temperature, solution $\mathrm{pH}$ was adjusted with $1 \mathrm{M} \mathrm{NaOH}$. The enzyme Alcalase was added to the solution (Table 1), and the reaction was monitored by continuous titration with $0.1 \mathrm{M} \mathrm{NaOH}$ in order to maintain the $\mathrm{pH}$ constant. The volume of $\mathrm{NaOH}$ consumed was recorded at regular intervals until the consumption variations were insignificant, indicating the end of protein hydrolysis. These data were used to calculate $\mathrm{DH}$, according to Adler-Nissen [7], as function of reaction time, in order to obtain the kinetic curves. Total hydrolysis time to reach maximum $\mathrm{DH}$ ranged from 40 to $200 \mathrm{~min}$, depending to assay.

Table 1. Experimental design (coded and real values) for enzymatic hydrolysis of okara protein concentrate.

\begin{tabular}{|c|c|c|c|c|}
\hline \multirow{2}{*}{ Design point } & \multicolumn{3}{|c|}{ Independent variables* } & \multirow{2}{*}{$\begin{array}{c}\text { Dependent variable } \\
\mathrm{DH}(\%)\end{array}$} \\
\hline & $\mathrm{T}\left({ }^{\circ} \mathbf{C}\right)$ & E/S (\%) & $\mathrm{pH}$ & \\
\hline 1 & $46(-1)$ & $1.4(-1)$ & $7.4(-1)$ & 22.5 \\
\hline 2 & $64(+1)$ & $1.4(-1)$ & $7.4(-1)$ & 19.4 \\
\hline 3 & $46(-1)$ & $4.1(+1)$ & $7.4(-1)$ & 27.2 \\
\hline 4 & $64(+1)$ & $4.1(+1)$ & $7.4(-1)$ & 25.1 \\
\hline 5 & $46(-1)$ & $1.4(-1)$ & $8.6(+1)$ & 19.8 \\
\hline 6 & $64(+1)$ & $1.4(-1)$ & $8.6(+1)$ & 23.0 \\
\hline 7 & $46(-1)$ & $4.1(+1)$ & $8.6(+1)$ & 30.8 \\
\hline 8 & $64(+1)$ & $4.1(+1)$ & $8.6(+1)$ & 28.0 \\
\hline 9 & $40(-1.68)$ & $2.75(0)$ & $8.0(0)$ & 23.6 \\
\hline 10 & $70(+1.68)$ & $2.75(0)$ & $8.0(0)$ & 16.5 \\
\hline 11 & $55(0)$ & $0.5(-1.68)$ & $8.0(0)$ & 16.5 \\
\hline 12 & $55(0)$ & $5.0(+1.68)$ & $8.0(0)$ & 25.9 \\
\hline 13 & $55(0)$ & $2.75(0)$ & $7.0(-1.68)$ & 26.5 \\
\hline 14 & $55(0)$ & $2.75(0)$ & $9.0(+1.68)$ & 31.0 \\
\hline 15 & $55(0)$ & $2.75(0)$ & $8.0(0)$ & 23.4 \\
\hline 16 & $55(0)$ & $2.75(0)$ & $8.0(0)$ & 23.4 \\
\hline 17 & $55(0)$ & $2.75(0)$ & $8.0(0)$ & 23.5 \\
\hline
\end{tabular}

* Independent variables correspond to the real values. Values enclosed in parentheses correspond to the coded values. $\mathrm{T}$ is temperature, $\mathrm{E} / \mathrm{S}$ is enzyme:substrate ratio and $\mathrm{DH}$ is degree of hydrolysis.

Experimental data were fitted to the following polynomial equation:

$D H=\beta_{0}+\beta_{1} X_{1}+\beta_{2} X_{2}+\beta_{3} X_{3}+\beta_{11} X_{1}^{2}+\beta_{22} X_{2}^{2}+\beta_{33} X_{3}^{2}+\beta_{12} X_{1} X_{2}+\beta_{13} X_{1} X_{3}+\beta_{23} X_{2} X_{3}$

where $\mathrm{DH}$ is degree of hydrolysis; $\beta_{0}$ is the constant regression coefficient; $\beta_{1}, \beta_{2}$, and $\beta_{3}$ are the linear regression coefficients; $\beta_{11}, \beta_{22}$, and $\beta_{33}$ are the quadratic regression coefficients; $\beta_{12}, \beta_{13}$ and $\beta_{23}$ are the cross-product regression coefficients; $X_{1}, X_{2}$, and $X_{3}$ represent the coded values of the independent variables (temperature, enzyme:substrate ratio and $\mathrm{pH}$, respectively).

The enzymatic hydrolysis of okara protein concentrate was optimized by response surface methodology for the maximum degree of hydrolysis. Then, the model (Eq. 1) was validated at optimized condition. Protein hydrolysate obtained under this condition was evaluated with respect to electrophoretic profile, antioxidant activity and isoflavone and amino acid contents.

\section{Sodium dodecyl sulfate-polyacrylamide gel electrophoresis (SDS-PAGE)}

Electrophoretic profiles of okara protein concentrate and hydrolysate obtained under optimum condition were carried out according to Laemmli [17] for proteins with molecular weight above $10 \mathrm{kDa}$, and according to Schagger and Jagow [18] for peptides with molecular weight below $26.6 \mathrm{kDa}$. A $4 \%$ stacking gel and separating gels of $20 \%$ and $10 \%$ acrylamide were used for each method, respectively. The samples were diluted in a buffer 
containing $0.5 \mathrm{M}$ Tris- $\mathrm{HCl} \mathrm{pH} 6.8,5 \% \beta$-mercaptoethanol in order to obtain a protein concentration of $4 \%$ and $2 \%$, respectively. For protein and peptides analysis, the samples were heated to $95^{\circ} \mathrm{C}$ for $5 \mathrm{~min}$ and $37^{\circ} \mathrm{C}$ for $15 \mathrm{~min}$, respectively. After cooling at room temperature, $10 \mu \mathrm{L}$ of each sample were applied on the gel with $2 \%$ SDS and $20 \%$ glycerol. Analyses were performed on a Mini-Protein II system (Electrophoresis Power Supply Loccus Biotechnology, São Paulo, Brazil). Apparent molecular weight of each protein band was estimated using molecular weight markers (Precision Plus Protein Standard, Bio-Rad Laboratories, Hercules, USA).

\section{Total amino acids content}

Amino acid composition of the protein hydrolysate was determined by digestion in $6 \mathrm{~N}$ $\mathrm{HCl} / 0.1 \%$ phenol at $110^{\circ} \mathrm{C}$ for $20 \mathrm{~h}$, according to the Pico-Tag method as described by White et al. [19]. After acid hydrolysis, sample derivatization was initiated by adding an ethanol:water:triethylamine:phenylisothiocyanate solution $(7: 1: 1: 1, \mathrm{v} / \mathrm{v})$, which was mixed using a vortex mixer and allowed to stand at room temperature for $20 \mathrm{~min}$. Identification of the amino acids was carried out by high-performance liquid chromatography using a reversed-phase column.

The nutritional quality of a protein source was evaluated by essential amino acid score (AS), which compares the levels of essential amino acids in sample with those of protein standard recommended by $\mathrm{FAO} / \mathrm{WHO}$ [20].

\section{Quantification of isoflavones}

Prior to analysis of isoflavones, the protein concentrate and hydrolysate were freeze-dried and isoflavone extraction was carried out according to Yoshiara et al. [21] using solution of water, ethanol and acetone. The separation and quantification of isoflavones were performed according to Handa et al. [22]. Aliquots of $1.4 \mu \mathrm{L}$ of filtrate were automatically injected into the liquid chromatograph UPLC (Acquity UPLC® System, Waters, USA) using reversed-phase column. The detector was a diode array with a $260 \mathrm{~nm}$ wavelength. For calibration curve, standard solutions were prepared of each isoflavone form (daidzin, glycitin, genistein, daidzein, glycitein, genistein from Sigma-Aldrich Co. St. Louis, USA; and acetyldaidzin, acetylglycitin, acetylgenistin, malonyldaidzin, malonylglycitin and malonylgenistin from Wako Pure Chemical Industries Ltd., Osaka, Japan). The isoflavone contents were expressed as $\mu \mathrm{mol} / \mathrm{g}$ solids.

\section{Antioxidant capacity}

ABTS method was carried out according to Sánchez-Gonzalez et al. 23. Protein concentrate and hydrolysate samples were added to $4 \mathrm{~mL}$ of ABTS+ solution. The absorbance was measured in a spectrophotometer at $730 \mathrm{~nm}$ after $6 \mathrm{~min}$ of incubation. An analytical curve with different concentrations of Trolox in ethanol (1.25 to $10 \mu \mathrm{M})$ was used for calibration.

Ferric reduction antioxidant power of the protein concentrate and hydrolysate was evaluated according to Benzie and Strain 24. Ten $\mu \mathrm{L}$ of sample were added to $110 \mu \mathrm{L}$ of distilled water and $900 \mu \mathrm{L}$ of FRAP reagent. After incubation at $37^{\circ} \mathrm{C}$ for $30 \mathrm{~min}$, the absorbance was measured in a spectrophotometer at $593 \mathrm{~nm}$. An analytical curve with different concentrations of Trolox $(50$ to $500 \mu \mathrm{M})$ was used for subsequent calculation of the results.

All measurements were performed in triplicate, and the results of antioxidant activity were expressed as $\mu \mathrm{M}$ Trolox equivalent (TE)/g solids.

\section{Statistical analysis}

The regression coefficients of predictive model (Eq. 1) were obtained using the Statistica 10 software (Statsoft, Tulsa, USA). Only coefficients within a confidence level 
above $90 \%$ were considered significant. The non-significant terms were eliminated and the model was tested for adequacy and goodness of fit by analysis of variance (ANOVA), evaluating the coefficient of determination (R2) and the F-test. When the calculated $F$ value was greater than the tabulated $F$ value, the variation was explained by the regression and not by the residues. Thus, the regression was significant and the model can be considered predictive. Antioxidant activities and isoflavone and amino acid contents of the protein concentrate and hydrolysate were analyzed by ANOVA and Tukey test (at $5 \%$ of significance), using the same software.

\section{RESULTS AND DISCUSSION}

\section{Enzymatic hydrolysis of okara protein concentrate}

The response maximum $\mathrm{DH}$ reached for each assay varied between 16.5 and $31.0 \%$ (Table 1). These results were fitted to a second order polynomial model at function of $\mathrm{T}, \mathrm{E} / \mathrm{S}$ and $\mathrm{pH}$ (Eq. 1). Although the quadratic factor $\mathrm{T}$ was not statistically significant at $95 \%$ significance level, this term was included in the model since it presented a $p$ value of 0.13 . The coefficient of determination $\left(R^{2}\right)$ for the adjusted model was 0.88 and the calculated $F$ (16.7) was higher than the tabulated $F$ (2.61). Thus, the regression was significant and the model can be considered predictive. A second order polynomial model (Eq. 2) was proposed to predict $\mathrm{DH}$ as function of encoded variables.

$\mathrm{DH}(\%)=22.7-1.2 \mathrm{~T}-0.8 \mathrm{~T}^{2}+3.1 \mathrm{E} / \mathrm{S}+1.1 \mathrm{pH}+2.3 \mathrm{pH}^{2}$

Response surfaces were generated from the predictive model, expressing the interaction between two independent variables. The third variable was maintained at the central point (Fig. 1).

In Figures $1 \mathrm{~A}$ and $\mathrm{B}$, a negative quadratic effect of temperature on $\mathrm{DH}$ can be seen, indicating a maximum $\mathrm{DH}$ value at temperatures around $55^{\circ} \mathrm{C}$. By increasing temperature up to $55^{\circ} \mathrm{C}$, there is an increase in kinetic energy of molecules, accelerating reaction rate. On the other hand, at $\mathrm{T}$ above $55^{\circ} \mathrm{C}$, a slight decrease on $\mathrm{DH}$ is observed, probably due to denaturation of enzyme structure and, as consequence, loss of its enzymatic activity [25]. With respect to E/S, a positive effect on $\mathrm{DH}$ can be observed in Figures $1 \mathrm{~A}$ and $1 \mathrm{C}$. Higher enzyme concentration increases reaction rate because there are more molecules of enzymes available per molecules of substrates. A decrease in $\mathrm{DH}$ is achieved by increase in $\mathrm{pH}$ up to 8.0; however, at $\mathrm{pH}$ superior, there is an increase in $\mathrm{DH}$, reaching the maximum value at $\mathrm{pH} 9.0$ (Fig. 1B and 1C). According to Whitaker [25], $\mathrm{pH}$ changes can affect the stability of enzymes, causing an irreversible denaturation of their conformational structure. As consequence, there is a continuous loss of enzyme activity.

Analyzing response surfaces (Fig. 1), the optimal condition to obtain maximum $\mathrm{DH}$ value was $55^{\circ} \mathrm{C}, \mathrm{E} / \mathrm{S}$ of $5.0 \%$ and $\mathrm{pH} 9.0$. This result is consistent with the product sheet of manufacture (Novozymes, Bagsvaerd, Denmark), in which the optimum $\mathrm{pH}$ and temperature ranges of Alcalase are $7.0-9.0$ and $50-60^{\circ} \mathrm{C}$, respectively. Optimization of enzymatic protein hydrolysis with Alcalase from different vegetal sources has been evaluated by several authors. Similar optimum conditions were reported by Yuan et al. [26]. However, Kanu et al. [27] established optimum conditions slightly distinct for enzymatic reaction of sesame flour protein. Thus, these results demonstrated the importance to optimize the enzymatic reaction for different protein sources. 


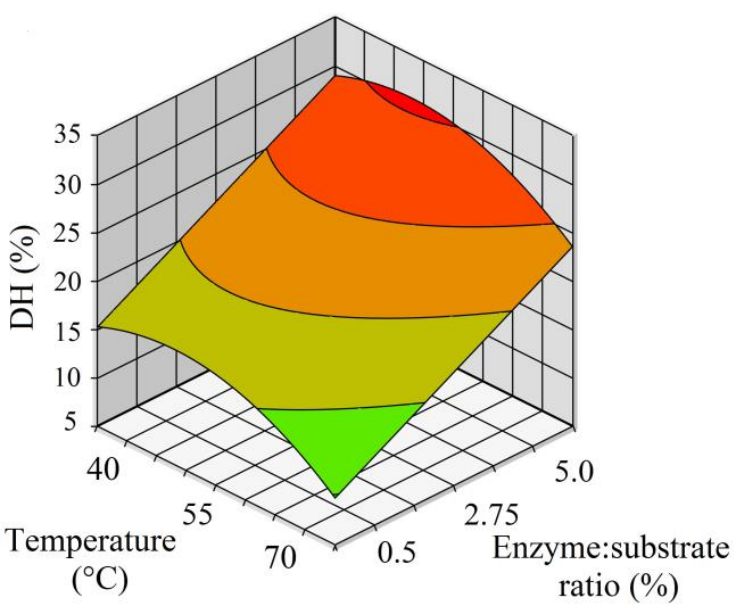

(a)

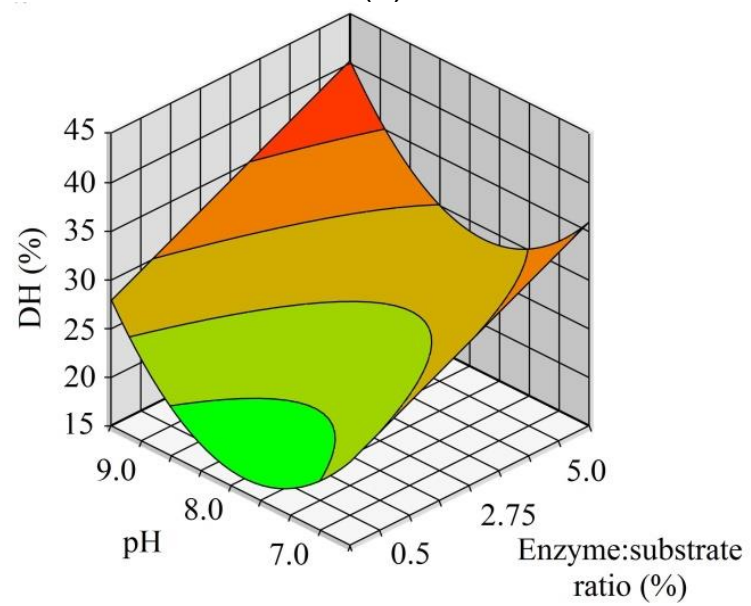

(c)

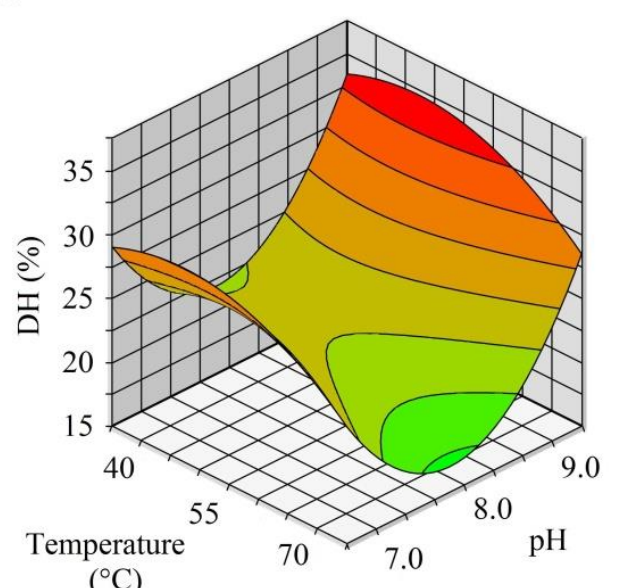

(b)

Figure 1. Influence of independent variables on the degree of hydrolysis $\mathrm{DH}$ : (a) enzyme:substrate ratio $\mathrm{E} / \mathrm{S}$ and temperature; (b) $\mathrm{pH}$ and temperature; (c) enzyme:substrate ratio $\mathrm{E} / \mathrm{S}$ and $\mathrm{pH}$.

\section{Model validation}

The enzymatic hydrolysis of protein concentrate was validated at optimum condition in triplicate in order to verify the adequacy of the second-order polynomial model (Eq. 2). After 200 min of reaction, the experimental $\mathrm{DH}$ was $35.5 \pm 0.2 \%$, close to the $\mathrm{DH}$ predicted by Equation $2(36.2 \%)$. The relative error between them was only $2 \%$, demonstrating that the obtained model was adequate to predict the $\mathrm{DH}$ within of the $\mathrm{T}, \mathrm{E} / \mathrm{S}$ and $\mathrm{pH}$ ranges studied in the current work.

\section{Evaluation of protein hydrolysate obtained under optimum condition}

The protein hydrolysate obtained under optimum condition was evaluated with respect to electrophoretic profile, isoflavone and amino acid contents, and antioxidant activity by ABTS and FRAP methods. In order to verify the effect of protein enzymatic hydrolysis, these analyses were also carried out in protein concentrate.

\section{Sodium dodecyl sulfate-polyacrylamide gel electrophoresis (SDS-PAGE)}

Electrophoretic profiles of protein concentrate and hydrolysate are shown in Figure 2. For protein concentrate, two distinct bands with molecular weight (MW) of $20 \mathrm{kDa}$ and 37 $\mathrm{kDa}$ can be seen, corresponding to glycinin (11S globulin). Glycinin is composed of acidic and basic subunits with $\mathrm{MW}$ between $36-40 \mathrm{kDa}$ and $18-20 \mathrm{kDa}$, respectively [28]. $\beta$-conglycinin (7S globulin) and glycinin (11S globulin) are the main soybean proteins; 
however, 7S fraction was not found. Possibly the subunits of 75 protein were lixiviated to the soymilk during its processing. Concerning to the hydrolyzed sample, the extent of hydrolysis was observed by disappearance of bands presented in protein concentrate (column 2) and the appearance of a diffuse band with a molecular weight below $10 \mathrm{kDa}$ (column 4). This result could be related to the high degree of hydrolysis (35.5\%) achieved in this study, which could have released free amino acids and short chain peptides.

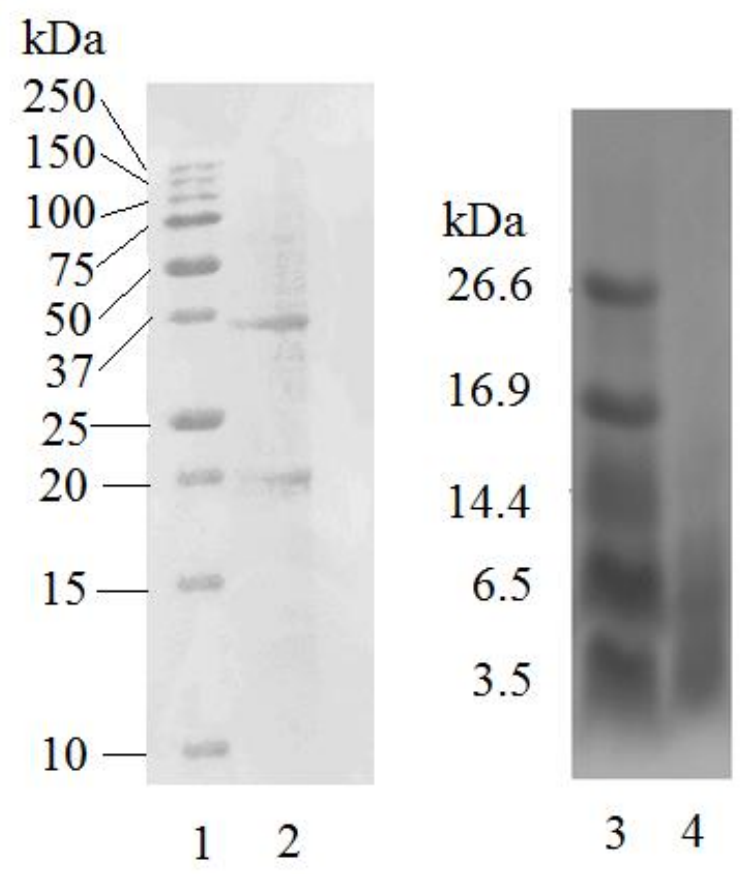

Figure 2. Electrophoresis of the protein concentrate (column 2) and protein hydrolyzate (column 4) compared with molecular weight markers (columns 1 and 3)

\section{Total amino acids composition}

Table 2 shows the total amino acid composition of the protein concentrate and hydrolysate. This analysis was carried out in order to explore possible correlations between amino acid composition and antioxidant activity (to be discussed below). On the whole, there were significant $(p<0.05)$ differences between samples, with exception of glycine, isoleucine, phenylalanine and valine. Samples had low content in sulphur-containing amino acids (methionine and cysteine) and high levels of glutamic and aspartic acid, which in agreement with results found by Yuan et al. [29]. These authors reported that the isolated acidic and basic polypeptides of soy glycinin, the main protein found in the current work (Fig. 2), were rich in glutamic and aspartic acid.

The nutritional quality of a protein source can be evaluated from its essential amino acid score (AS). The AS compares the levels of essential amino acids sample with those of protein standard recommended by FAO/WHO [20]. Analyzing Table 2, there were no limiting amino acids $(A S>1)$ in the samples, with exception for methionine in protein hydrolysate. This result was expected, since this sulfur-containing amino acid is the limiting essential amino acid in soybeans and other legume species, because the major storage proteins, the globulins, are low in this compound [30]. 
Table 2. Total amino acid composition ( $\mathrm{g} / 100 \mathrm{~g}$ protein) of protein concentrate and protein hydrolysate under optimum conditions.

\begin{tabular}{|c|c|c|c|c|c|}
\hline $\begin{array}{c}\text { Total } \\
\text { amino acid }\end{array}$ & $\begin{array}{c}\text { FAO/WHO } \\
\text { [20] * }\end{array}$ & $\begin{array}{c}\text { Protein } \\
\text { concentrate }\end{array}$ & $\begin{array}{c}\text { Protein } \\
\text { hydrolysate }\end{array}$ & $\mathrm{AS}_{\text {concentrate }}$ & $\mathrm{AS}_{\text {hydrolysate }}$ \\
\hline \multicolumn{6}{|l|}{ Non-essential } \\
\hline - Alanine & & $4.12 \pm 0.01 \mathrm{a}$ & $4.33 \pm 0.0 \mathrm{~b}$ & & \\
\hline - Arginine & & $7.06 \pm 0.00 a$ & $8.33 \pm 0.01 b$ & & \\
\hline - Aspartic acid & & $\begin{array}{c}11.50 \pm 0.01 \\
a\end{array}$ & $11.35 \pm 0.01 b$ & & \\
\hline - Cysteine & & $0.84 \pm 0.01 \mathrm{a}$ & $0.73 \pm 0.02 b$ & & \\
\hline - Glutamic acid & & $\begin{array}{c}21.24 \pm 0.04 \\
a\end{array}$ & $19.65 \pm 0.05 b$ & & \\
\hline - Glycine & & $4.18 \pm 0.00 a$ & $4.21 \pm 0.02 \mathrm{a}$ & & \\
\hline - Proline & & $5.09 \pm 0.01 a$ & $5.01 \pm 0.01 b$ & & \\
\hline - Serine & & $5.11 \pm 0.00 \mathrm{a}$ & $5.16 \pm 0.01 b$ & & \\
\hline - Tyrosine & & $3.87 \pm 0.01 \mathrm{a}$ & $3.83 \pm 0.01 b$ & & \\
\hline \multicolumn{6}{|l|}{ Essential } \\
\hline - Histidine & 1.9 & $2.29 \pm 0.01 \mathrm{a}$ & $2.23 \pm 0.01 b$ & 1.21 & 1.17 \\
\hline - Isoleucine & 2.8 & $5.42 \pm 0.00 \mathrm{a}$ & $5.43 \pm 0.00 a$ & 1.94 & 1.94 \\
\hline - Leucine & 6.6 & $7.60 \pm 0.00 a$ & $7.76 \pm 0.01 b$ & 1.15 & 1.18 \\
\hline - Lysine & 5.8 & $5.81 \pm 0.00 \mathrm{a}$ & $5.91 \pm 0.01 b$ & 1.00 & 1.02 \\
\hline - Methionine & $2.5^{\star \star}$ & $1.77 \pm 0.01 \mathrm{a}$ & $1.65 \pm 0.02 b$ & 1.04 & 0.95 \\
\hline - Phenylalanine & $6.3^{\star * *}$ & $5.52 \pm 0.00 \mathrm{a}$ & $5.55 \pm 0.01 \mathrm{a}$ & 1.49 & 1.49 \\
\hline $\begin{array}{l}\text { - Threonin } \\
\text { - Tryptophan }\end{array}$ & 3.4 & $\begin{array}{c}3.39 \pm 0.00 \mathrm{a} \\
\mathrm{Nd}\end{array}$ & $\begin{array}{c}3.68 \pm 0.00 \mathrm{~b} \\
\mathrm{Nd}\end{array}$ & 1.00 & 1.08 \\
\hline - Valine & 3.5 & $5.17 \pm 0.01 \mathrm{a}$ & $5.19 \pm 0.00 \mathrm{a}$ & 1.48 & 1.48 \\
\hline $\begin{array}{r}\mathrm{AAE} \\
\text { Hydrophobic }\end{array}$ & nino acid & $\begin{array}{l}36.97 \\
34.69\end{array}$ & $\begin{array}{c}37.4 \\
34.92\end{array}$ & & \\
\hline
\end{tabular}

Values represent means of two determinations \pm standard deviations. Different letters are considered significantly different at the $5 \%$ level $(p<0.05)$. Nd is not determined; AAE is total essential amino acid content and AS is essential amino acid score = amino acid in test sample/reference FAOMHO [20]. * Reference FAO/WHO (1991) pattern (essential amino acid for child of 2 - 5 years). ${ }^{* *}$ Methionine + cysteine. ${ }^{* * *}$ Phenylalanine + tyrosine

\section{Isoflavone content}

Protein concentrate and hydrolysate presented 6.60 and $16.44 \mu \mathrm{mol} / \mathrm{g}$ of total isoflavones content, respectively (Table 3 ). These values were higher than those reported for crude okara [31]. In addition, the high protein content in the hydrolysate (56.7\%, dry basis) make them attractive to be incorporate into food systems, since soy proteins are an efficiently isoflavones delivery vehicle capable of providing significant absorption into circulation [32]. In other words, simultaneous ingestion of soy protein with isoflavone possesses synergistic effect.

Protein hydrolysate presented higher total isoflavones than protein concentrate. This fact may be probably as result of changes in isoflavone-protein interactions during hydrolysis, enhancing the extractability of isoflavones. Owing to their phenolic nature, isoflavones associate with the hydrophobic interior of the globular soybean proteins and thus are hidden from the aqueous phase [13]. In order to verify that proteins limit isoflavone extraction, Malaypally and Ismail [13] subjected different soy systems to protein hydrolysis prior solvent extraction. As results, efficiency of isoflavone extraction was influenced by protein content and denaturation state. Lu et al. [11] reported that protein hydrolysis and accompanying release of associated isoflavones with interior moiety of protein enhanced their extractability. Nufer et al. [12] suggested that the protein hydrolysis can increase the 
efficiency of extraction of isoflavones, since protein molecule lost some its primary, secondary and tertiary structure. According to the authors, protein hydrolysis most likely disrupted protein-isoflavone interactions, including hydrophobic interactions, hydrogen bonds and electrostatic interactions, enhancing release of isoflavones.

Table 3. Isoflavone profile (dry basis) in the protein concentrate and hydrolyzate.

\begin{tabular}{|c|c|c|c|c|c|}
\hline \multirow[b]{2}{*}{ Groups } & \multirow[b]{2}{*}{$\begin{array}{l}\text { Isoflavones } \\
\text { forms }\end{array}$} & \multicolumn{2}{|c|}{ Protein concentrate } & \multicolumn{2}{|c|}{ Protein hidrolysate } \\
\hline & & $\begin{array}{c}\text { Isoflavones } \\
\text { content } \\
(\mu \mathrm{mol} / \mathrm{g})\end{array}$ & $\begin{array}{c}\% \text { in } \\
\text { relation } \\
\text { to total }\end{array}$ & $\begin{array}{c}\text { Isoflavones } \\
\text { content } \\
(\mu \mathrm{mol} / \mathrm{g})\end{array}$ & $\begin{array}{c}\% \text { in } \\
\text { relation } \\
\text { to total }\end{array}$ \\
\hline \multirow{4}{*}{ Malonylglycosides } & Malonyldaidzin & $\mathrm{Nd}$ & - & $\mathrm{Nd}$ & - \\
\hline & Malonylglycitin & $\mathrm{Nd}$ & - & $\mathrm{Nd}$ & - \\
\hline & Malonylgenistin & $0.73 \pm 0.05$ & 11.1 & $\mathrm{Nd}$ & - \\
\hline & Subtotal & 0.73 & 11.1 & $\mathrm{Nd}$ & - \\
\hline \multirow{4}{*}{ Acetylglycosides } & Acetyldaidzin & $\mathrm{Nd}$ & - & $\mathrm{Nd}$ & - \\
\hline & Acetylglycitin & $\mathrm{Nd}$ & - & $\mathrm{Nd}$ & - \\
\hline & Acetylgenistin & $\mathrm{Nd}$ & - & $\mathrm{Nd}$ & - \\
\hline & Subtotal & $\mathrm{Nd}$ & - & $\mathrm{Nd}$ & - \\
\hline \multirow{4}{*}{$\beta$-glycosides } & Daidzin & $0.24 \pm 0.01$ & 3.6 & $\mathrm{Nd}$ & - \\
\hline & Glycitin & $\mathrm{Nd}$ & - & $\mathrm{Nd}$ & - \\
\hline & Genistin & $0.57 \pm 0.04 a$ & 8.6 & $2.19 \pm 0.27 b$ & 13.3 \\
\hline & Subtotal & 0.81 & 12.3 & 2.19 & 13.3 \\
\hline \multirow{5}{*}{ Aglycones } & Daidzein & $1.59 \pm 0.10 a$ & 24.1 & $3.15 \pm 0.39 b$ & 19.2 \\
\hline & Glycitein & $\mathrm{N} d$ & - & $4.69 \pm 0.62$ & 28.5 \\
\hline & Genistein & $3.47 \pm 0.22 a$ & 52.6 & $6.41 \pm 0.85 b$ & 39.0 \\
\hline & Subtotal & 5.06 & 76.7 & 14.25 & 86.7 \\
\hline & $\begin{array}{c}\text { Total } \\
\text { isoflavones }\end{array}$ & 6.60 & 100.0 & 16.44 & 100.0 \\
\hline
\end{tabular}

Values represent the mean of 2 determinations \pm standard deviation. Different letters indicate significant difference at $5 \%(p<0.05)$ between protein concentrate and hydrolysate. $\mathrm{Nd}=$ not detected.

Differences on isoflavone profile for both samples can be observed in Table 3. For protein hydrolysate of okara, the absence of malonylgenistyn, initially present in protein concentrate, is observed. It is well know that malonylglycosides conjugates are thermally unstable and can undergo de-esterification reactions into their respective nonconjugated $\beta$-glycosides [14]. The increase on total aglycone content in protein hydrolysate, representing about $86.7 \%$ in relation to total isoflavones, was observed when compared to protein concentrate (Table 3). This fact could be attributed to the release of isoflavones from the interior of globular soybean proteins after their hydrolysis [11,12], exposing the glycosides to their conversion to aglycones during the reaction. Heat treatment influences soy isoflavone profile, favoring conversion of glycosides to aglycones by $\beta$-glucosidase action [14]. Investigating the effect of temperature on hydrothermal treatment of soybeans, Lima and Ida [33] found higher conversion of $\beta$-glycosides to aglycones at $55^{\circ} \mathrm{C}$. This result corroborates with the current study, because protein enzymatic hydrolysis was carried out at $55^{\circ} \mathrm{C}$. Wu and Muir [34], studying changes on isoflavone content during protein hydrolysis of defatted soybean meal, reported a remarkable increase in aglycone content. The authors attributed this fact to the contaminated $\beta$-glucosidase present in Alcalase protease in a concentration of $0.03 \mathrm{U} / \mathrm{g}$.

\section{Antioxidant capacity}

Both samples exhibit antioxidant capability; however, for ABTS method, the protein hydrolysate possessed higher antioxidant activity $(383.49 \pm 0.06 \mu \mathrm{M}$ Trolox equivalent/g 
solids) than the protein concentrate $(58.29 \pm 0.01 \mu \mathrm{M}$ Trolox equivalent/g solids). For FRAP method, same behavior was observed: the antioxidant activities of protein hydrolysate and concentrate were $15.32 \pm 0.02$ and $2.41 \pm 0.01 \mu \mathrm{M}$ Trolox equivalent/g solids, respectively.

These results showed that hydrolysis process led to the increase on antioxidant capacity. Several studies report that enzymatic hydrolysis of soy protein enhanced antioxidant capacity, which was related to the release of bioactive peptides [35]. The release of peptides from enzymatic hydrolysis of okara protein can be observed by the high DH achieved in this work (35.5\%) and electrophoresis analysis (Fig. 2). According to García et al. [4], antioxidant activity of proteins has been related to their amino acid composition. However, such property of these amino acids residues is limited by the tertiary structure, because many amino acids with antioxidant potential can be buried within the protein core where they are inaccessible to prooxidants. Therefore, enzymatic hydrolysis favors the exposure of antioxidant amino acids in proteins, increasing antioxidant activity of peptides.

Analyzing the results, samples had higher scavenging ABTS+ radical than reducing power (FRAP). Reducing power is a result of presence of antioxidant components that are electron donors, reacting with free radicals. According to Carrasco-Castilla et al. [36], the most reactive amino acids tend to be cysteine, methionine, tryptophan, tyrosine, histidine and lysine. These amino acids in protein hydrolysate were present in a relative low concentration (14.6 and $14.3 \mathrm{~g} / 100 \mathrm{~g}$ protein, respectively) (Table 2). On the other hand, sample had a high content of hydrophobic amino acids (Table 2), whose presence in bioactive peptides is related to the radical scavenging mechanisms [37]. Thus, the amino acids composition of protein hydrolysate may explain the low reducing power as compared to scavenging ability of sample.

Besides being related to bioactive peptides, protein hydrolysate had greater antioxidant capacity than protein concentrate probably also due to the high aglycone content (Table 3). Aglycones, mainly genistein and daidzein forms, have superior antioxidant capacity than their corresponding glycosides forms [36].

\section{CONCLUSION}

The optimum condition to obtain higher $\mathrm{DH}$ was found: $55^{\circ} \mathrm{C}, \mathrm{pH} 9$ and enzyme:substrate ratio of $5.0 \%$. Under these conditions, a DH of $35.5 \%$ was achieved. The enzymatic hydrolysis favored extraction of isoflavones as well as conversion of glycosides to aglycones, which display greater bioavailability than their corresponding glycosides. Greater antioxidant activity in the protein hydrolysate was observed, which could be due to the high aglycone content and the release of bioactive peptides with antioxidant capacity. This study demonstrated that it is possible to transform okara, a byproduct of little commercial value, to protein hydrolysate with higher nutritional value and antioxidant properties. Such product presents a great potential as an ingredient in food formulation.

Funding: This research was funded by ARAUCARIA FOUNDATION OF PARANÁ, grant number 160/2014, and BRAZILIAN NATIONAL COUNCIL FOR SCIENTIFIC AND TECHNOLOGICAL DEVELOPMENT CNPq, grant number 473117/2013-4. LEK was Araucaria Foundation Research Fellow (501/2014). LEK and Ell are CNPq Research Fellow.

Conflicts of Interest: The authors declare no conflict of interest. The funders had no role in the design of the study; in the collection, analyses, or interpretation of data; in the writing of the manuscript, or in the decision to publish the results.

\section{REFERENCES}

1. Wang, H.J.; Murphy, P.A. Mass balance study of isoflavones during soybean processing. J Agri Food Chem 1996, 44, 2377-2383.

2. Guimarães, R.M.; Silva, T.E.; Lemes, A.C.; Boldrin, M.C.F.; Silva, M.A.P.; Egea, M.B. Okara: A soybean by-product as an alternative to enrich vegetable paste. LWT - Food Sci Technol 2018, 92, 593-599. 
3. Koopman, R.; Crombach, N.; Gijsen, A.P.; Walrand, S.; Fauquant, J.; Kies, A.K.; Lemosquet, S.; Saris, W.H.; Boirie, Y.; van Loon, L.J. Ingestion of a protein hydrolysate is accompanied by an accelerated in vivo digestion and absorption rate when compared with its intact protein. $A m J$ Clin Nutr 2009, 90, 106-115.

4. García, M.C; Puchalska, P.; Esteve, C.; Marina, M.L. Vegetable foods: A cheap source of proteins and peptides with antihypertensive, antioxidante, and other less occurrence bioactivities. Talanta 2013, 106, 328-349.

5. Jackson, C.J.C.; Dini, J.P.; Lavandier, C.; Rupasinghe, H.P.V.; Faulkner, H.; Poysa, V.; Buzzell, D.; DeGrandis, S. Effects of processing on the content and composition of isoflavones during manufacturing of soy beverage and tofu. Process Biochem 2002, 37, 1117-1123.

6. Kao, T.H.; Chen, B.H. Functional components in soybean cake and their effects on antioxidant activity. J Agric Food Chem 2006, 54, 7544-7555.

7. Adler-Nissen, J. Enzymic hydrolysis of food protein; Elsevier Applied Science Publishers: London, UK, 1986.

8. Sbroggio, M.F.; Montilha, M.S.; Figueiredo, V.R.G.; Georgetti, S.R.; Kurozawa, L.E. Influence of the degree of hydrolysis and type of enzyme on antioxidant activity of okara protein hydrolysates. Food Sci Technol 2016, 36, 375-381.

9. Jakovetić, S.; Luković, V.; Jugović, B.; Gvozdenović, M.; Grbavčić, S.; Jovanović, J.; Knežević-Jugović, Z. Production of antioxidant egg white hydrolysates in a continuous stirred tank enzyme rector coupled with membrane separation unit. Food Bioprocess Tech 2015, 8, 287-300.

10. Huang, Y.; Ruan, G.; Qin, Z.; Li, H.; Zheng, Y. Antioxidant activity measurement and potential peptides exploration from hydrolysates of novel continuous microwave-assisted enzymolysis of the Scomberomorus niphonius protein. Food Chem 2017, 223, 89-95.

11. Lu, W.; Chen, X.-W.; Wang, J.-M.; Yang, X.-Q.; Qi, J.-R. Enzyme-assisted subcritical water extraction and characterization of soy protein from heat-denatured meal. J Food Eng 2016, 169, 250-258.

12. Nufer, K.R.; Ismail, B.; Hayes, D.K. The effects of processing and extraction conditions on content, profile, and stability of isoflavones in a soymilk system. J Agric Food Chem 2009, 57, 1213-1218.

13. Malaypally, S.P.; Ismail, B. Effect of protein content and denaturation on the extractability and stability of isoflavones in different soy systems. J Agric Food Chem 2010, 58, 8958-8965.

14. Chien, J.T.; Hsieh, H.C.; Kao, T.H.; Chen, B.-H. Kinetic model for studying the conversion and degradation of isoflavones during heating. Food Chem 2005, 91, 425-434.

15. AOAC. Official Methods of Analysis, $20^{\text {th }}$ ed.; Association of Official Analytical Chemists International: Washington, D.C., USA, 2016.

16. Rodrigues, M.I.; lemma, A.F. Planejamento de experimentos e otimização de processos, 3rd ed.; Cárita Editora: Campinas, Brazil, 2014.

17. Laemmli, U.K. Cleavage of structural proteins during the assembly of the head of bacteriophage T4. Nature 1970, 227, 685-689.

18. Schagger, H.; Jagow, G.V. Tricine-sodium dodecyl sulfate-polyacrylamide gel electrophoresis for the separation of proteins in the range from 1 to $100 \mathrm{kDa}$. Anal Biochem 1987, 166, 368-79.

19. White, J.A.; Hart, R.J.; Fry, J.C. An evaluation of the Waters Pico-Tag system for the amino-acid analysis of food materials. $J$ Autom Chem 1986, 8, 170-177.

20. FAO/WHO. Food and Agriculture Organization/World Health Organization. Evaluation of protein quality. Joint FAO/WHO report. FAO Food Nutrition: Rome, Italy, 1991.

21. Yoshiara, L.Y.; Madeira, T.B.; Delaroza, F.; Silva, J.B.; Ida, E.I. Optimization of soy isoflavone extraction with different solvents using the simplex-centroid mixture design. Int J Food Sci Nutr 2012, 63, 978-986.

22. Handa, C.L.; Couto, U.R.; Vicensoti, A.H.; Georgetti, S.R.; Ida, E.I. Optimization of soy flour fermentation parameters to produce $\beta$-glucosidase for bioconversion into aglycones. Food Chem 2014, 152, 56-65. 
23. Sánchez-Gonzalez, I.; Jiménez-Escrig, A.; Saura-Calixto, F. In vitro antioxidant activity of coffees brewed using different procedures (italian, espresso and filter). Food Chem 2005, 90,133-139.

24. Benzie, I.F.F.; Strain, J.J. The ferric reducing ability of plasma (FRAP) as a measure of "antioxidant power": The FRAP assay. Anal Biochem 1996, 239, 70-76.

25. Whitaker, J.R. Principles of enzymology for the food sciences; Marcel Dekker.Inc.: New York, USA, 1994.

26. Yuan, X.; Gu, X.; Tang, J. Optimization of the production of Momordica charantia L. Var. abbreviata Ser. protein hydrolysates with hypoglycemic effect using Alcalase. Food Chem 2008, 111, 340-344.

27. Kanu, P.J.; Kanu, J.B.; Sandy, E.H.; Kandeh, J.B.A.; Mornya, P.M.P.; Huiming, Z. Optimization of enzymatic hydrolysis of defatted sesame flour by different proteases and their effect on the functional properties of the resulting protein hydrolysate. Am J Food Technol 2009, 4, 226-240.

28. Liu, C.; Wang, H.; Cui, Z.; He, X.; Wang, X.; Zeng, X.; Ma, H. Optimization of extraction and isolation for $11 \mathrm{~S}$ and $7 \mathrm{~S}$ globulins of soybean seed storage protein. Food Chem 2007, 102, 1310-1316.

29. Yuan, D.-B.; Yang, X.-Q.; Tang, C.-H.; Zheng, Z.-X.; Min, W.; Ahmad, I.; Yin, S.-W. Physicochemical and functional properties of acidic and basic polypeptides of soy glycinin. Food Res Int 2009, 42, 700-706.

30. Liu, K. Soybeans: chemistry, technology, and utilization; Chapman \& Hall: New York, USA, 1997.

31. Muliterno, M.M.; Rodrigues, D.; Lima, F.S.; Ida, E.I.; Kurozawa, L.E. Conversion/degradation of isoflavones and color alterations during the drying of okara. LWT - Food Sci Technol 2017, 75, 512-519.

32. Andrade, J.E.; Twaddle, N.C.; Helferich, W.G.; Doerge, D.R. Absolute bioavailability of isoflavones from soy protein isolate-containing food in female BALB/c mice. J Agric Food Chem 2010, 58, 4529-4536

33. Lima, F.S.; Ida, E.I. Optimisation of soybean hydrothermal treatment for the conversion of $\beta$-glucoside isoflavones to aglycones. LWT-Food Sci Technol 2014, 56, 232-239.

34. Wu, J.; Muir, A.D. Isoflavone during protease hydrolysis of deffated soybean meal. Food Chem 2010, 118, 328-332.

35. Zhang, Q.; Tong, X.; Sui, X.; Wang, Z.; Qi, B.; Li, Y.; Jiang, L. Antioxidant activity and protective effects of Alcalase-hydrolyzed soybean hydrolysate in human intestinal epithelia Caco-2 cells. Food Res Int 2018, 111, 256-264.

36. Carrasco-Castilla, J.; Hernández-Álvarez, A.J.; Jiménez-Martínez, C.; Jacinto-Hernández, C.; Alaiz, M.; Girón-Calle, J.; Vioque, J.; Dávilla-Ortiz, G. Antioxidant and metal chelating activities of peptide fractions from phaseolin and bean protein hydrolysates. Food Chem 2012, 135, 1789-1795.

37. Lee, C.H.; Yang, L.; Xu, J.Z.; Yeung, S.Y.V.; Huang, Y.; Chen, Z.-Y. Relative antioxidant activity of soybean isoflavones and their glycosides. Food Chem 2005, 90, 735-741. 